Karmawibangga : Historical Studies Journal, Vol: 01, No: 01, 2019: 33-42

ISSN:- E-ISSN:

htpps://journal.upy.ac.id/index.php/karmawibangga

\title{
SEJARAH PERKEMBANGAN MATARAM ISLAM KRATON PLERED
}

\author{
Siswanta
}

Prodi Pendidikan Sejarah Universitas PGRI Yogyakarta

siswanta.upy@gmail.com

\begin{abstract}
Abstrak
Amangkurat Agung (I) adalah raja Mataram yang diangkat menjadi raja untuk menggantikan ayahnya, dan mendapat gelar Susuhunan Ing Alaga. Ketika dinobatkan secara resmi pada tahun 1646, ia bergelar Kanjeng Susuhunan Prabu Amangkurat Agung. Pada tahun 1647 ibu kota Mataram dipindah dari Karta ke Plered yang berjarak kira-kira $2 \mathrm{~km}$. Istana baru ini dibangun dengan menggunakan bahan dari batu bata, sedangkan istana lama di Karta terbuat dari kayu. Berbeda dengan Keraton sebelumnya, Keraton Plered dikelilingi dengan tembok-tembok setinggi 18-20 kaki dengan kedalaman 812 kaki. Raja Amangkurat I wafat pada masa bergerak mundur di Tegal pada Juli 1677. Kemudian digantikan oleh Putra mahkota dengan memakai gelar Amangkurat II, dan diterima oleh bangsawan Jawa di Tegal (kampung halaman neneknya).
\end{abstract}

Kata kunci: Kerajaan Mataram, Kraton Plered, Amangkurat Agung

\section{Abstract \\ Amangkurat Agung (I) was the king} of Mataram who was appointed king to replace his father, and earned the title Susuhunan Ing Alaga. When officially crowned in 1646, he was called Kanjeng Susuhunan Prabu Amangkurat Agung. In 1647 the capital of Mataram was moved from Karta to Plered. The new palace was constructed using brick materials, while the old castle in the Karta was made of wood. The Plered Palace is located east of Karta, about $2 \mathrm{~km}$ away. Unlike the previous Palace, the Plered Kingdom is surrounded by 18-20-foot walls with a depth of 8-12 feet. King Amangkurat I died on his retreat in Tegal in July 1677. It was then replaced by the Crown Prince using the title Amangkurat II, and was received by Javanese nobility in Tegal (his grandmother's hometown).

Keywords: Mataram Kingdom, Plered Kingdom, Amangkurat Agung 


\section{PENDAHULUAN}

Kerajaan Mataram Islam adalah kerajaan yang berdiri pada abad ke-17 di Pulau Jawa. Kerajaan ini dipimpin oleh keturunan Ki Ageng Pemanahan, sebagai suatu kelompok ningrat keturunan penguasa Majapahit. Asal-usulnya adalah suatu Kadipaten di bawah Kasultanan Pajang, berpusat di "Hutan Mentaok". Raja pertama adalah Sutowijoyo (Panembahan Senapati), putra dari Ki Ageng Pemanahan. Berkat keberhasilannya membunuh Arya Penangsang dalam perang perebutan tahta atas Demak, Kyai Ageng Pemanahan mendapat hadiah tanah di Mataram dari Sultan Pajang. Di tempat inilah Kyai Ageng Pemanahan dan pengikutnya kemudian membuka hutan untuk dijadikan tempat permukiman (Adrisijanti, 2000: 40).

Kerajaan Mataram pada masa keemasannya pernah menyatukan tanah Jawa dan sekitarnya, termasuk Madura. Kerajaan ini pernah dua kali menyerang VOC di Batavia untuk mencegah semakin berkuasanya perdagangan itu, namun ironisnya justru harus menerima bantuan VOC pada masa-masa akhir menjelang keruntuhannya.

Dasar-dasar kehidupan maritim kurang dimiliki oleh Mataram dan tidak memungkinkan untuk mendirikan pelabuan di pantai laut selatan Pulau Jawa karena ombaknya terlalu besar. Sehingga kasultanan Mataram tidak memungkinkan menjadi kerajaan Maritim karena pusat kerajaannya berada di pedalaman (Slamet Mulyana, 2007: 226).

Mataram merupakan kerajaan berbasis agraris atau pertanian dan relatif tidak kuat dalam hal maritim. Kerajaan ini meninggalkan beberapa jejak sejarah yang dapat dilihat hingga kini, seperti kampung Matraman di Batavia (sekarang bernama Jakarta) dikuasai oleh Belanda. Sehingga di tahun 1628 dan 1629 Kerajaan Mataram pimpinan Sultan Agung Hanyakrakusuma menyerang Batavia. Penyerangan pertama gagal namun serangan kedua berhasil membunuh J.P. Coen. Basis penyerangan Kerajaan Mataram inilah yang sekarang disebut dengan daerah Matraman. Selanjutnya Kalimalang karena pada saat pasukan Kerajaan Mataram menyerang Batavia di tahun 1628 menemukan sungai yang bukan mengarah ke laut atau ke utara. Namun mengalir ke arah barat sehingga disebut dengan Kalimalang. Dalam bahasa Jawa arti dari kali adalah sungai sedangkan malang adalah melintang. Begitu juga Pademangan saat Kerajaan Mataram menyerang Batavia pada tahun 1628 banyak panglima perang yang tidak pulang ke Kerajaan Mataram. Sebab takut dipenggal kepalanya karena gagal menguasai Kota Batavia. Salah satu panglima tersebut menetap di Kota Batavia dan menjadi demang (penguasa setingkat desa dalam budaya Jawa). Karena itu daerah tersebut diberi nama Pademangan.

Akhirnya Sultan Agung, raja yang dikenal karena berbagai ekspansi wilayah sekaligus wawasan kebudayaannya, salah satunya mengembangkan kalender Jawa dengan memadukan tarikh Hijriah dengan Saka pada tahun 1633. Setelah wafat dimakamkan di Imogiri, ia digantikan oleh putranya yang bergelar Amangkurat Agung (I). Pada masa pemerintahan Amangkurat Agung ini telah berbelok haluan tidak lagi seperti pemerintahan ayahnya yang menentang VOC, akan tetapi justru bersekutu dengannya dan mendapat dukungan penuh dari VOC.

\section{METODE PENELITIAN}

Penelitian ini menggunakan metode kepustakaan (library research), karena data-data yang diperoleh melalui studi pustaka. Adapun proses penelitian yakni, diawali dari penentuan subjek, perumusan problema, survai, pengumpulan sumber, analisa sumber, kesimpulan sementara dan berakhir dengan seminar umum, follow up hasil seminar, disimpulkan dan dituangkan dalam tulisan. Dalam pengumpulan sumber ini penulis menggunakan teknik pengumpulan data dengan cara studi kepustakaan, yaitu mengumpulkan data 
dari literatur dengan cara menelaah isinya melalui fakta-fakta dan dokumen-dokumen yang telah ada. Setelah kebenaran dan keaslian sumber dinilai dapat dipertanggungjawabkan, maka fakta yang ada digabungkan menjadi satu sehingga diperoleh rangkaian peristiwa sejarah yang bermakna Penulisan ini merupakan hasil penelitian yang dilakukan berdasarkan sistematika yang telah disusun penulis. Setiap pembahasan ditempuh melalui diskripsi dan analisis, dengan selalu memperhatikan aspek kronologis dari suatu peristiwa.

\section{HASIL DAN PEMBAHASAN}

\section{Masa awal Pemerintahan Mataram}

Sutawijaya naik tahta setelah ia merebut wilayah Pajang dari Hadiwijaya dengan gelar Panembahan Senopati. Pada saat itu wilayahnya hanya di sekitar Jawa Tengah, mewarisi wilayah Kerajaan Pajang. Pusat pemerintahan berada di hutan Mentaok, wilayah yang terletak di sebelah timur Kota Yogyakarta dan selatan Bandar Udara Adisucipto sekarang. Lokasi kraton (tempat kedudukan raja) pada masa awal terletak di Kotagede. Sesudah ia meninggal kekuasaan dilanjutkan putranya Raden Mas Jolang yang setelah naik tahta bergelar Prabu Hanyokrowati.

Pemerintahan Prabu Hanyokrowati tidak berlangsung lama karena ia wafat akibat kecelakaan saat sedang berburu di hutan Krapyak. Karena itu ia juga disebut Susuhunan Seda Krapyak atau Panembahan Seda Krapyak yang artinya Raja yang wafat di Krapyak. Setelah itu tahta beralih sebentar ketangan putra keempat Mas Jolang yang kemudian bergelar Adipati Martoputro. Ternyata Adipati Martoputro mengalami sakitsakitan. sehingga tahta beralih ke putra sulung Mas Jolang yang bernama Mas Rangsang pada masa pemerintahan Mas Rangsang, Mataram mengalami masa puncak keemasan.

Pemerintahan Sultan Agung (1613-1645)

Sesudah naik tahta Mas Rangsang bergelar Sultan Agung Prabu Hanyokrokusumo atau lebih dikenal dengan sebutan Sultan Agung. Pada masa pemerintahan Sultan Agung para ulama yang berada di kasultanan terbagi dalam tiga bagian. Yaitu ulama yang masih berdarah bangsawan, ulama yang bekerja sebagai tenaga birokrasi, dan ulama pedesaan yang tidak menjadi tenaga brokrasi. Sebagai penguasa Sultan Agung sangat menghargai para ulama karena mereka memiki moral dan ilmu pengetahuan yang tinggi. Jika ingin membuat kebijakan Sultan Agung selalu meminta nasehat dan pertimbangan kepada para ulama (Darmawijaya, 2010 : 74-75).

Peran ulama pada saat itu lebih menitikberatkan pada Islamisasi terhadap budaya-budaya yang masih melekat dihati masyarakat Mataram. Seperti Sunan Kalijogo, beliau adalah seorang ulama yang selalu berusaha dengan keras agar ajaran agama Islam mudah diterima oleh masyarakat yang sudah kuat tertanam nilai kepercayaannya sebelum Islam masuk. Beliau dengan sabar mensiarkannya melalui karya seni yang sudah mentradisi di masyarakat.

Pindahnya pusat pemerintahan dari pesisir utara Jawa ke daerah pedalaman yang bersifat agraris dan telah dipengaruhi oleh budaya dan tradisi sebelumnya. Demikianlah kondisi keberadaan Islam semenjak berpusat di Mataram campur tangan budaya setempat yang kemudian terkenal dengan Islam Kejawen (M. Yahya Harun, 1995 : 30-31).

Penggunaan gelar Sayidin Panatagama oleh Panembahan Senopati menunjukkan bahwa sejak awal berdirinya Mataram telah dinyatakan sebagai pemimpin dan pengatur agama. Mataram mewarisi agama dan peradaban Islam dari kerajaan Pesisir yang telah berdiri sebelumnya. Sunan Kalijogo sebagai penghulu di masjid Demak mempunyai pengaruh besar di Mataram baik sebagai pemimpin agama maupun pembimbing di bidang politik. Hubungan yang sangat erat dengan Cirebon memiliki peranan penting bagi perkembangan Islam di Mataram. Sifat mistik dari keraton Cirebon 
merupakan unsur yang penting, sehingga memudahkan Islam diterima oleh masyarakat Jawa di Mataram. Islam tersebut tentu adalah Islam sinkritisme yang menyatukan diri dengan unsur-unsur Hindu-Budha (Daliman, 2012 : 190).

Pada masanya Mataram melakukan ekspansi untuk mencari pengaruh di Jawa. Pada puncak kejayaannya, wilayah kekuasaan Mataram mencakup sebagian Pulau Jawa dan Madura, kira-kira gabungan Jawa Tengah, sebagian besar Jawa Barat, Daerah Istimewa Yogyakarta, dan Jawa Timur sekarang, dengan pengecualian daerah Blambangan atau yang sekarang adalah wilayah Probolinggo hingga Banyuwangi. Sultan Agung memindahkan lokasi kraton dari Kota Gede ke Karta.

Akibat terjadi perselisihan dalam penguasaan perdagangan antara Mataram dengan VOC yang berpusat di Batavia, Mataram lalu berkoalisi dengan Kasultanan Banten dan Kasultanan Cirebon dan terlibat dalam beberapa peperangan antara Mataram melawan VOC.

Masih mengenai ekspansi Kerajaan Mataram, Banten dan Batavia merupakan dua wilayah yang menjadi target serangan berikutnya. Serangan ke Banten dilakukan karena kerajaan itu menolak mengakui kekuasaan Mataram atas seluruh Jawa. Sementara itu, serangan ke Batavia dipicu oleh kemarahan Sultan Agung terhadap VOC yang menolak membantunya dalam serangannya ke Surabaya (D.G.E. Hall, tt: 274). Serangan yang berlangsung dua kali (tahun 1628 dan 1629) itu tidak membuahkan hasil. Persoalan logistik menjadi penyebab utama.

Kegagalan serangan ke wilayah barat tidak mengurangi ambisi Susuhunan Ingalaga Mataram untuk mewujudkan kembali wilayah Majapahit maupun Demak. Sehubungan dengan hal itu, mulamula ia menempatkan penduduk dari Jawa Tengah dan Sumedang di daerah Krawang yang kala itu berupa semak belukar. Selain membuka hutan tersebut, mereka juga diwajibkan untuk menjadikan Krawang sebagai daerah pertanian padi Mataram. Selanjutnya, membangun jalan-jalan yang menghubungkan Krawang dengan Mataram. Berikutnya, Sultan juga bersekutu dengan orang orang-orang Portugis di Malaka dan orang-orang Inggris di Banten. Adapun pengiriman beras ke Batavia dilarang dan sebagai gantinya pedagang-pedagang beras diperintahkan untuk langsung mengirimkan dagangannya ke Malaka.

Kegagalan penyerangan ke Batavia juga mengubah arah politik Kerajaan Mataram. Salah satu perubahan yang mencolok, sebagaimana tercatat dalam Daghregister, adalah penarikan kapalkapal perang Mataram dari Teluk Krawang pada awal Maret 1634 (J.J. de Graaf, 1986: 197). Selanjutnya, ekspansi wilayah yang tadinya mengarah ke barat beralih ke timur, terutama wilayah Blambangan dan Bali. Usaha tersebut berhasil dengan baik. Blambangan menyerah pada tahun 1639 dan mayoritas penduduknya dipindahkan ke pusat kerajaan meskipun akhirnya bersama-sama dengan Bali menghalau serangan Mataram dengan berani luar biasa dan mempertahankan kebebasannya (R. Soekmono, 1981: 62).

Penyerangan Kerajaan Mataram ke Blambangan dan Bali dilandasi pula dengan sentimen kepercayaan. Hal itu dilatarbelakangi oleh semangat serta keberhasilan hubungan baik dengan kelompok Islam di Mekah. Bahkan, karena termotivasi berkaitan dengan religi pula, penguasa Mataram mengirimkan utusan ke Mekah, yang pada tahun 1641 kembali ke Mataram dengan membawa ahli-ahli agama sebagai penasihat istana sekaligus gelar baru; Sultan Abdul Muhammad Maulana Mataram atau lebih terkenal dengan nama Sultan Agung.

Lima tahun kemudian, Sultan Agung menghembuskan napas terakhir. Babad Tanah Jawi melukiskan suasana kelabu dan suram di hari kematian itu; mendung hitam menyelimuti langit Mataram dan di luar gemuruh suara Merapi bercampur 
dengan hujan badai. Akhirnya, raja yang dikenal karena berbagai ekspansi wilayah sekaligus wawasan kebudayaannya, salah satunya mengembangkan kalender Jawa dengan memadukan tarikh Hijriah dengan Saka pada tahun 1633. Setelah wafat dimakamkan di Imogiri, ia digantikan oleh putranya yang bergelar Amangkurat Agung (I).

\section{Pemerintahan Amangkurat Agung (1645-1677)}

Amangkurat Agung ( I ) adalah raja Mataram berikutnya. Pada tahun 1645 ia diangkat menjadi raja Mataram untuk menggantikan ayahnya, dan mendapat gelar Susuhunan Ing Alaga. Ketika dinobatkan secara resmi tahun 1646, ia bergelar Amangkurat atau Mangkurat, lengkapnya adalah Kanjeng Susuhunan Prabu Amangkurat Agung. Dalam bahasa Jawa kata Amangku yang berarti "memangku", dan kata Rat yang berarti "bumi", jadi Amangkurat berarti "memangku bumi". Demikianlah, ia menjadi raja yang berkuasa penuh atas seluruh Mataram dan daerah-daerah bawahannya, dan pada upacara penobatannya tersebut seluruh anggota keluarga kerajaan disumpah untuk setia dan mengabdi kepadanya.

Di tahun pertamanya, ia menandatangi perjanjian damai dengan VOC yang berisi enam pasal. Di antaranya mengatur pengiriman utusan Belanda ke Mataram, kesediaan Belanda mengatur perjalanan ulama Mataram, pembebasan tawanan Belanda di Mataram, penyerahan orang-orang berutang, perang bersama, serta pelayaran bebas di Kepulauan Maluku. Perdamaian yang ditandatangani pada tanggal 24 September 1646. itu disambut suka cita oleh Belanda. Dentuman-dentuman meriam sebagai ekspresi perayaan perdamaian terdengar dari loji-loji Belanda (H.J. de Graaf, 1987: 88). Perjanjian tersebut oleh Amangkurat I dianggap sebagai bukti takluk VOC terhadap kekuasaan Mataram.

Berikutnya, 4 Februari 1947, Amangkurat I menerima kunjungan pertama dari Jan Hermansz, utusan Belanda pertama di masa pemerintahannya. Dua ekor kuda pilihan terbaik, dua sekesel yang indah, tiga puluh empat potong kesturi, air mawar setempayan, dan satu tong anggur Spanyol dipersembahkan kepadanya untuk melegalkan perjanjian tersebut (H.J. de Graaf, 1987: 89).

Pada tahun 1647 ibu kota Mataram dipindah dari Karta ke Plered. Seperti yang tertulis dalam babad tanah Jawi "Kamu semua harus membuat batu-bata, karena saya mau angkat kaki dari Karta, saya ingin membangun kota di Plered" (Meinsma, 1874\}. Istana baru ini lebih banyak dibangun dari batu bata, sedangkan istana lama di Karta terbuat dari kayu. Letaknya di sebelah timur Karta, kira-kira $2 \mathrm{~km}$. Berbeda dengan Keraton sebelumnya, Keraton Plered dikelilingi dengan tembok-tembok setinggi 18-20 kaki dengan kedalaman 8-12 kaki (Darja de Wever, 1995: 24, 27). Perpindahan istana tersebut diwarnai pemberontakan Raden Mas Alit atau Pangeran Danupoyo, adik Amangkurat I yang menentang penumpasan tokoh-tokoh senior. Pemberontakan ini mendapat dukungan para ulama namun berakhir dengan kematian Mas Alit. Amangkurat I ganti menghadapi para ulama. Mereka semua, termasuk anggota keluarganya, sebanyak 5.000 orang lebih dikumpulkan di alunalun untuk dibantai.

Rijklof van Goens melukiskan kondisi Plered sebagai berikut. Dalam perjalanan menuju Plered sekitar 18 - 19 mil dari kota pelabuhan Semarang, terletak pintu gerbang pertama, disebut Selimbi. Pada pintu gerbang ini terdapat sebuah benteng, yang dihuni sekitar $1500-1600$ orang. Dengan dijaga oleh para prajurit kraton, semua yang lewat gerbang dicatat oleh juru tulis. Sekitar 1 - 1,5 mil dari gerbang Selimbi, terbentang daerah Mataram yang subur, sawah sangat luas hingga batasnya tidak tampak. Desa-desa sangat subur banyak ditemui sepanjang jalan. Diantara sawah-sawah ditemui 
perbukitan yang ditanami pohon buahbuahan. Diperkirakan pintu gerbang Selimbi merupakan pintu masuk wilayah negara agung Mataram. Jalan antara gerbang Selimbi dan gerbang Tadi (gerbang masuk kedua), berjarak sekitar 7 mil. Setelah gerbang kedua, terlihat pegunungan mengitari pusat kerajaan Plered (Darja de Wever, 1995: 25-26).

$$
\text { Rijklof van Goens juga }
$$

menggambarkan bahwa desa-desa di antara kedua pintu gerbang tersebut, padat penduduk. Setiap desa berpenduduk sekitar 100 - 150 orang, bahkan ada yang berpenghuni sekitar 1000 - 1500 orang. Pusat kerajaan dicapai setelah melalui garbang ketiga, yang dinamai Kaliajir. Dari gerbang ini terdapat jalan menuju istana raja, sepanjang 2 mil. Antara gerbang Kaliajir dan istana raja, banyak ditemui rumah para pangeran dan berbagai residen. Pagar kota diperkirakan berukuran luas $2 \times 2$ mil, dengan ketinggian tembok sekitar $6-7$ meter. Beberapa komponen di dalam tembok keraton adalah sebagai berikut sitinggil, bangsal witana, mandungan, sri menganti, pecaosan, sumur gumuling tempat memandikan keris pusaka, masjid panepen (Suronoto), prabayeksa, bangsal kencana, bangsal kemuning, bangsal manis, gedong kuning, dan tempat tinggal abdi dalem kedhondhong (Adrisijanti, 2000:76).

Di sebelah utara komplek kraton terdapat alun-alun berukuran sekitar $300 \mathrm{x}$ $400 \mathrm{~m}$, dengan Masjid di sebelah baratnya. Di dalam komplek masjid terdapat makam. Desa Kauman berada di sekitar masjid, diperkirakan dihuni oleh para pemuka agama dan pegawai masjid. Rumah-rumah para pangeran terletak di sebelah utara alun-alun, menuju gerbang Kaliajir. Di sekitar desa Segarayasa, dulu terdapat danau buatan, terletak di sebelah selatan kraton. Di tengah danau (Segarayasa) tersebut terdapat sebuah pulau, dipergunakan untuk meditasi dan sembahyang raja (Darja de Wever, 1995: 25-26).
Keindahan bangunan Keraton Plered karena dilengkapi dengan danau buatan atau Segarayasa, yang berfungsi tidak hanya sebagai tempat rekreasi keluarga raja, tetapi bangunan ini juga sebagai tempat perikanan, perairan dan latihan perang. Di sebelah utara Segoroyoso terdapat areal perbukitan Gunung Kelir, disini merupakan tempat makam Panjang Mas dan Ratu Mas Malang. Gapuro makam Gunung Kelir keberadaan sekarang telah melah mengalami kehancuran dengan dikelilingi tembak batu tebal dengan banyak bagian yang telah runtuh akibat gempa. Tembok ini mengelilingi area seluas $900 \mathrm{~m} 2$, dimana di dalamnya terdapat makam Dalang Panjang Mas, Ratu Mas Malang dan makam-makam lainnya yang terlihat cukup tua. Ratu Mas Malang semula merupakan istri Panjang Mas seorang dalang Keraton Mataram sejak masa Panembahan Sedo Krapyak.

Tampaknya Amangkurat I jatuh hati pada Ratu Mas Malang dan berniat untuk memperistrinya. Akhirnya Panjang Mas dibunuh dan jasatnya dikubur di Makam Gunung Kelir yang terletak di sebelah timur Keraton Plered. Sepeninggal Panjang Mas, Amangkurat I memperistri Ratu Mas Malang menjadi selir yang kemudian dijadikan permaisuri, namun tiba-tiba meninggal dunia.

Pembangunan komponen-komponen Keraton Plered dilakukan secara bertahap. Hal tersebut dapat diketahui dari Serat Babad Momana yang menyebutkan tahun pendirian beberapa bangunan, meliputi kadipaten (1569 J), masjid agung (1571 J), prabayeksa (1572 J), segarayasa (1574 J). Keterangan lain yang dapat diperoleh adalah pembangunan sitinggil bagian bawah dengan batu (1572 J), pembangunan witana atau anjungan di sitinggil (1574 J), permulaan pembangunan karadenan atau kediaman putra mahkota (1576 J), dan pembangunan bangsal di srimenganti (1585 J) (Graaf, 1987:13).

Pemerintahan di Plered bertumpu pada kekuatan militer. Rijklof van Goens misalnya mencatat bahwa Amangkurat I 
memiliki 920.000 tentara dan 115.500 prajurit beristinggar. Tentara maupun prajurit beristinggar itu tidak hanya dipimpinnya sendiri melainkan juga dipimpin oleh vasal-vasalnya yang dikerahkan ketika Mataram menghadapi peperangan. Pemerintahan Amangkurat I di Kraton Plered juga penuh represi. Represi pertama yang dirasakan terkait dengan kegemaran Amangkurat I mengumpulkan besi untuk dibuat keris, tombak, senapan, dan kendaraan laut. Berbagai penangkapan, pembelengguan, pemerasan, dan perbuatan tirani lain dilakukan untuk mengumpulkan uang demi bisa membeli besi (Daghregister, 7 Desember 1656 via H.J. de Graaf, 1987: 130). Selain itu, represi pemerintahan Amangkurat I juga dirasakan dalam ranah ekonomi. Per Garebeg Mulud 27 November 1659, rakyat dikenakan pajak kepala. Besarnya berbeda-beda, seperti: $7 / 4$ ringgit bagi penduduk biasa, 9/4 ringgit bagi pemilik tanah, dan 3 ringgit bagi penduduk yang hidup dari usaha pelayaran (Daghregister, 13 November 1659 via H.J. de Graaf, 1987: 131). Tidak ketinggalan, Amangkurat I juga melakukan penutupan pelabuhan-pelabuhan. Penutupan pelabuhan itu dilakukan demi monopoli beras juga kayu sebagai komoditas perdagangan Mataram. Adapun penduduk yang kedapatan tetap berlayar ataupun melakukan perdagangan via pelabuhan dibunuh oleh penguasa setempat atas perintahnya.

Tabel 1. Kekuatan militer Mataram di bawah Amangkurat Agung (I)

\begin{tabular}{clc}
\hline No & Pemimpin & Jumlah \\
\hline 1 & Pangeran & 50.000 tentara \\
& Purbaya & 48.000 prajurit \\
& & bertombak \\
& & 2.000 prajurit \\
& & beristiggar \\
\hline 2 & Pangeran & 50.000 tentara \\
& Surabaya & 48.000 prajurit \\
& & bertombak \\
& & 2.000 prajurit \\
& & beristiggar \\
\hline
\end{tabular}

\begin{tabular}{|c|c|c|}
\hline 3 & Pangeran Blitar & $\begin{array}{l}40.000 \text { tentara } \\
1.000 \text { prajurit } \\
\text { beristinggar }\end{array}$ \\
\hline \multirow[t]{2}{*}{4} & Pangeran & 40.000 tentara \\
\hline & Salaran & $\begin{array}{l}1.000 \text { prajurit } \\
\text { beristinggar }\end{array}$ \\
\hline \multirow[t]{2}{*}{5} & Pangeran & 100.000 tentara \\
\hline & Cirebon & $\begin{array}{l}600 \text { prajurit } \\
\text { beristinggar }\end{array}$ \\
\hline \multirow[t]{2}{*}{6} & Pangeran & 20.000 tentara \\
\hline & Madura & $\begin{array}{l}500 \text { prajurit } \\
\text { beristinggar }\end{array}$ \\
\hline \multirow[t]{2}{*}{7} & Pangeran & 20.000 tentara \\
\hline & Blambangan & $\begin{array}{l}500 \text { prajurit } \\
\text { beristinggar }\end{array}$ \\
\hline \multirow[t]{2}{*}{8} & Pangeran Tuban & 20.000 tentara \\
\hline & & $\begin{array}{l}500 \text { prajurit } \\
\text { beristinggar }\end{array}$ \\
\hline \multirow[t]{3}{*}{9} & Pangeran Tuban & 20.000 tentara \\
\hline & & 500 prajurit \\
\hline & & beristinggar \\
\hline \multirow[t]{3}{*}{10} & Pangeran & 20.000 tentara \\
\hline & Pemalang & 500 prajurit \\
\hline & & beristinggar \\
\hline \multirow[t]{3}{*}{11} & Pangeran & 20.000 tentara \\
\hline & Demak & 500 prajurit \\
\hline & & beristinggar \\
\hline \multirow[t]{3}{*}{12} & Pangeran Pati & 40.000 tentara \\
\hline & & 1.000 prajurit \\
\hline & & beristinggar \\
\hline \multirow[t]{2}{*}{13} & Susuhunan & 20.000 tentara \\
\hline & & $\begin{array}{l}1.000 \text { prajurit } \\
\text { beristinggar }\end{array}$ \\
\hline
\end{tabular}

Sumber: Rijklof van Goens via Darja de Wever, 1995: 41

Selain itu, pemerintahan Amangkurat juga memberlakukan monopoli terhadap beras, gula hitam, gula putih, papan, balok, dan garam. Di samping itu, per 24 Juni 1657 Amangkurat I memberikan pinjaman uang sebesar 10.000 rial kepada para bawahannya, terutama penguasa Pesisir, dan harus dikembalikan dua kali lipat selama satu tahun. Bagi bangsawanbangsawan Mataram yang tidak terbiasa berdagang, kebijakan itu membuat mereka kesulitan sehingga perampasan dan peningkatan besaran pajak kepala terhadap penduduk pun dilakukan. Ditambah 
dengan penderitaan-penderitaan yang belum dapat diatasi, sebagai akibat peperangan yang terjadi pada masa pemerintahan Sultan Agung, pemberontakan-pemberontakan pun mulai bermunculan. Amangkurat I juga berselisih dengan putra mahkotanya, yaitu Raden Mas Rahmat yang menjadi Adipati Anom. Perselisihan ini dilatarbelakangi oleh berita bahwa jabatan Adipati Anom akan dipindahkan kepada Pangeran Singasari (putra Amangkurat I lainnya).

Pada tahun 1661 Mas Rahmat melancarkan aksi kudeta tetapi mengalami kegagalan. Amangkurat I menumpas seluruh pendukung putranya itu. Sebaliknya, Amangkurat I juga gagal dalam usaha meracun Mas Rahmat tahun 1663. Perselisihan memuncak tahun 1668 pada saat Mas Rahmat merebut calon selir ayahnya yang bernama Rara Oyi.

Amangkurat I menghukum mati Pangeran Pekik mertuanya sendiri, yang dituduh telah menculik Rara Oyi untuk Mas Rahmat. Mas Rahmat sendiri diampuni setelah dipaksa membunuh Rara Oyi dengan tangannya sendiri. Salanjutnya muncul pemberontakan besar yang dimulai di Madura di bawah pimpinan Trunojoyo pada tahun 1674, seorang pangeran dari Arisbaya (Soekmono, 1981: 68).

Dengan bantuan pelaut-pelaut Makasar yang dipimpin Kraeng Galesong, pemberontakan Trunojoyo pun meluas di seluruh Jawa Timur dan daerah-daerah Pesisir Jawa Tengah. Puncaknya, ibu kota Plered berhasil dikuasai pada tahun 1677 dan Amangkurat I meninggal di Tegalwangi atau Tegalarum dalam usahanya mencari perlindungan Belanda. Ia meninggalkan pesan kepada penerusnya, Adipati Anom, untuk meminta bantuan kepada Belanda (Soekmono, 1981: 68).

Pemberontakan Trunojoyo sangat berpengaruh terhadap luas wilayah Batavia. Mataram tidak hanya berkewajiban membayar semua biaya perang yang dikeluarkan Belanda untuk membantu menumpas pemberontakan Trunojoyo melainkan juga menjamin konsesi perdagangan Belanda dengan menyerahkan banyak sekali daerah di selatan Batavia, pelabuhan serta distrik Mataram, juga sejumlah kota pantai sebagai jaminan. Sementara itu, jatuhnya Kraton Plered membuat Adipati Anom sebagai penguasa baru Mataram kembali memindahkan ibu kota. Kartasura dipilih sebagai pusat pemerintahan. Adapun gelar yang diambil ialah Amangkurat II (16771703).

Raja Amangkurat I wafat semasa bergerak mundur di Tegal pada Juli 1677. Putra mahkota menggantikan ayahnya dan memakai gelar Amangkurat II, dan diterima oleh bangsawan Jawa di Tegal (kampung halaman neneknya) dan juga oleh VOC (Ricklefs, 2008 ; 92). Namun, dia gagal untuk mengukuhkan kekuasaannya di kota terdekat, Cirebon, yang penguasanya memutuskan untuk menyatakan kemerdekaan dari Mataram dengan dukungan dari Kasultanan Banten. Selanjutnya, adik laki-lakinya Pangeran Puger (kelak Pakubuwana I) merebut ibu kota yang kini hancur, menolak bergabung sebagai loyalis Amangkurat II, dan menyatakan dirinya sebagai raja dengan gelar Ingalanga Mataram (Pigeaud, 1976 ; 76).

Karena tidak memiliki tentara dan harta kekayaan dan tidak dapat mengukuhkan kekuasaannya, Amangkurat memutuskan untuk bersekutu dengan VOC. Pada saat ini, Laksamana Speelman berada di Jepara, berlayar ke sana dari Surabaya setelah mendengar jatuhnya ibu kota. Pasukannya telah merebut kembali kota-kota pesisir penting di Jawa Tengah, termasuk Semarang, Demak, Kudus, dan Pati. Amangkurat pindah ke Jepara dengan kapal VOC pada September 1677. Raja harus menyetujui konsesi luas yang dituntut VOC sebagai imbalan untuk memulihkan monarkinya. Dia menjanjikan VOC pendapatan dari semua kota pelabuhan di pantai utara. Dataran tinggi Priangan dan Semarang akan diserahkan kepada VOC. Raja juga setuju untuk mengakui yurisdiksi kekuasaan VOC atas 
semua orang non-Jawa yang tinggal di wilayahnya. Sejarawan Belanda H. J. de Graaf berkomentar bahwa dengan melakukan ini, VOC, sebagai sebuah korporasi, terlibat dalam "spekulasi berbahaya", yang mereka harapkan akan terbayar di masa depan ketika rekan mereka akan memperoleh kembali kekuasaannya atas Mataram (Pigeaud, 1976 ;. 77).

Pasukan VOC dengan Mataram membuat kemajuan yang lamban melawan para pemberontak. Pada awal tahun 1678 penguasaan mereka terbatas pada beberapa kota di pantai utara bagian tengah. Pada 1678, Speelman menjadi Direktur Jenderal VOC, menggantikan Rijcklof van Goens, yang menjadi Gubernur Jenderal (Speelman kelak menjadi Gubernur Jenderal pada 1681). Komandonya di Jepara diserahkan kepada Anthonio Hurdt, yang tiba pada Juni 1678 (Ricklefs, 2008 ;93).

Pemerintahan di Kartasura sepenuhnya dibayang-bayangi Belanda. Tidak hanya memburu Trunojoyo dan membawanya di hadapan Amangkurat II, Trunojoyo mati ditikam oleh Amangkurat II. Belanda juga mendirikan sebuah garnisun tepat di depan istana setahun kemudian. Pembangunan itu dilakukan dengan alasan untuk melindungi Amangkurat II dari serangan musuh. Di luar itu, pemerintahan dilakukan dengan pengawalan Belanda.

\section{Kehancuran Kraton Plered.}

Bangunan Kraton Plered rusak karena adanya serangan Trunojoyo yang dibantu oleh Kraeng Galengsong karena merasa tidak puas atas sikap Amangkurat Agung yang telah bersekutu dengan Belanda kemudian, adanya perang Diponegoro, dan pembuatan pabrik gula Plered. Nama Plered diambil dari luapan air yang mengalir dari Segarayasa di celah perbukitan sebelah selatan tempuran sungai Gajah Wong dengan sungai Opak.

Keberadaan Kraton Plered sekarang sangat memprihatinkan, sudah hancur rata dengan tanah, jejak-jejak Kraton bisa dilihat dari situs - situs peninggalan. Situssitus yang masih ada sampai sekarang antara lain Sumur Gumuling, umpak masjid Agung Kraton Plered, umpak bekas pendopo kraton Karta, Jagang/kanal, pondasi benteng Kraton, bekas tanggul buatan, bekas pondasi benteng keraton yang ada di Pungkuran, dan situs yang lain menjadi nama perkampugan seperti, kampung Segarayasa, kampung Kedaton, kampung Keputren, kampung Kauman, dan lain sebagainya.

\section{KESIMPULAN}

Perkembangan Kerajaan Mataram Islam sejak awal berdirinya dari Kota Gede sampai dengan masa menjelang keruntuhannya di Keraton Plered, telah mengalami pasang surut sesuai eranya masing-masing. Amangkurat Agung ( I ) adalah raja Mataram yang diangkat menjadi raja untuk menggantikan ayahnya (Sultan Agung), dan mendapat gelar Susuhunan Ing Alaga. Ketika dinobatkan secara resmi pada tahun 1646, ia bergelar Kanjeng Susuhunan Prabu Amangkurat Agung. Pada tahun 1647 ibu kota Mataram dipindah dari Karta ke Plered. Pada masa pemerintahan Amangkurat Agung telah mengalami tanda-tanda kemunduran, yakni dengan adanya serangan yang dipimpin Trunojoyo telah memporak porandakan pertahanan Keraton Plered. Raja Amangkurat Agung (I) terpaksa harus melarikan diri minta perlindungan pada VOC. Akhirnya raja Amangkurat Agung meninggal dunia dalam pelariannya di Tegal pada Juli 1677. Kemudian digantikan oleh Putra mahkota dengan memakai gelar Amangkurat II, dan diterima oleh bangsawan Jawa di Tegal (kampung halaman neneknya).

\section{DAFTAR PUSTAKA}

Adrisijanti, Inajati. (2000). Arkeologi Perkotaan Mataram Islam. Jendela. Yogyakarta

Daliman, A. (2012). Islamisasi dan perkembangan kerajaan-kerajaan Islam di Indonesia, Yogyakarta, Ombak. 
Darja de Wever. (1995). Javaense Reyse,

Terra Incognita, Amsterdam

Darmawijaya. (2010). Kesultanan Islam

Nusantara, Jakarta, pustaka Al-

Kautsar

De Graaf, DR. H.J. (1985). Awal

Kebangkitan Mataram Masa

Pemerintahan Senopati, Grafitipers. (1985). Puncak

Kekuasaan Mataram Politik

Ekspansi Sultan Agung, Grafitipers.

(1987).

Disintegrasi Mataram di Bawah

Mangkurat I, Grafitipers.

Gegevens Over Djokjakarta. (1925). Hoofdplaats Djokjakarta

Goens, Rijklof van. (1956). De vijf gezantschapsreizen naar het hof van Mataram, 1648-1654, Den Haag.

Harun M. Yahya (1995). Kerajaan Islam Nusantara abad XVI dan XVII, Yogyakarta Kurnia Kalam Sejahtera.

Mainsma, J.J.. 1874-1877, Babad Tanah Djawi, 's-Gravenhage, Dua jilid

Muljana, Slamet, 2007, Runtuhnya Krajaan Hindu-Jawa dan Timbulnya Negara-Negara Islam di Nusantara, Yogyakarta PT. LkiS Pelangi Aksara

Pigeaud, Theodore Gautrier Thomas. (!976. Islamic State in Jawa 15001700: Eigt Dutch Books and Articles by Dr H.J. de Graaf, Den Haag: Martinus Nijhoff ISBN 90-2471876-7

Ricklefs, M.C. (2008). A History of Modern Indonesia Since C. 1200, Palgrave Macmillan.

Soekmono, R., 1981, Pengantar Sejarah Kebudayaan Indonesia, Yogyakarta, Kanisius

Yusuf, Mundzirin, dkk, 2007, Sejarah Peradaban Islam di Indonesia, Yogyakarta, Kelompok Penerbit Pinus. 